\title{
CHOLANGITIS OF PANCREATITIS? DOES THE ANGIOTENSIN-CONVERTING ENZYME GENOTYPE FAVOR EITHER?
}

\author{
Kasap $\mathrm{E}^{1 *}$, Akyıldız $\mathrm{M}^{2}$, Akarca $\mathrm{U}^{2}$
}

*Corresponding Author: Elmas Kasap, Department of Gastroenterology, Faculty of Medicine, Celal Bayar University, Manisa, Turkey; Tel.: +90-236-2330115-+90-542-2457238; Fax: +90236-2370213 ; e-mail: elmaskasap@yahoo.com

\begin{abstract}
Acute cholangitis and pancreatitis are serious complications of gallstones, with considerable morbidity and mortality. Angiotensin-converting enzyme (ACE) is an exopeptidase that is important in regulating blood pressure, metabolizing bradykinin and in maintaining an inflammatory response. To determine whether the ACE genotype determines occurrence of cholangitis or pancreatitis we examined ACE I/D genotypes in 31 patients who had cholangitis, 44 patients with biliary pancreatitis and 157 healthy individuals. The patients had been hospitalized at the Department and Intensive Care Faculty of Medicine, Ege University, İzmir, Turkey. The patients were recalled 4 years later and their prognosis was evaluated. The ACE II genotype was found at a higher frequency in the cholangitis and biliary pancreatitis patients when compared with the healthy subjects $(p<0.05)$. There was no significant difference between cholangitis and biliary pancreatitis cases regarding the genotype and allele distribution $(p>0.05)$. Recurrence of infection occurred more frequently in the patients with the DD genotype, although it was not significant according to the first assessment $(p>0.05)$. The ACE gene
\end{abstract}

1 Department of Gastroenterology, Faculty of Medicine, Celal Bayar University, Manisa, Turkey

2 Department of Gastroenterology, Faculty of Medicine, Ege University, Bornova, İzmir, Turkey polymorphism did not seem to favor development of either cholangitis or pancreatitis.

Key Words: Cholangitis, Pancreatitis, Angiotensin-converting enzyme (ACE), Common bile duct stone

\section{INTRODUCTION}

Gallstones are frequent in the Western world, with up to $10 \%$ of the general population affected. Gallstone prevalence is higher in the elderly and in women [1]. Most series indicate that the prevalence rate of gallstones in women between the ages of 20 and 55 years varies from 5 to $20 \%$, and in those older than 50 years, from 25 to $30 \%$. The prevalence rate in men is approximately one-half that in women for a given age group and the prevalence in children is $0.13 \%$ [2]. Acute cholangitis and pancreatitis are the most serious complications of gallstones, with considerable morbidity and mortality $[1,3]$.

Acute cholangitis is an infectious disease of the biliary tract ranging in severity from a mild form with fever and jaundice to a severe form with septic shock. Patients are febrile, often have abdominal pain, and are jaundiced [4]. There is usually leukocytosis, and serum alkaline phosphatase and bilirubin levels are generally elevated [4,5]. Approximately $85 \%$ of cases are caused by an impacted stone in the common bile duct, with resulting bile stasis [6].

Acute pancreatitis is an acute inflammatory process with varied etiologies [7], but its pathogenesis is 
not fully understood [8]. Blockages of the duodenal papilla or ampulla of Vater are the common characteristics of the disease being most commonly due to gallstones, causing approximately $40 \%$ of cases [9]. Gallstone pancreatitis may be associated with cholangitis but is also common as a separate entity [10]. A popular mechanism of gallstone pancreatitis is that an impacted gallstone in the distal common bile duct obstructs the pancreatic duct, increasing pancreatic pressure and damaging ductal and acinar cells [11].

Several studies have shown the existence of local renin-angiotensin system (RAS) components in brain, heart, kidney, pancreas, adrenal glands and gonads $[12,13]$. Local RAS functions include the regulation of cell growth, differentiation, proliferation and apoptosis, reactive oxygen species (ROS) generation, tissue inflammation and fibrosis, and hormonal secretion [14].

The systemic hormonal RAS regulates electrolyte balance, fluid and blood pressure. The angiotensin-converting enzyme (ACE) is responsible for the conversion of angiotensin I to angiotensin II, which is a potent vasoconstrictor $[15,16]$ and also inactivates bradykinin, a vasodilator produced by the kallikrein-kinin system, which has major implication in acute pancreatitis and other inflammations $[17,18]$. The ACE gene insertion/deletion (I/D) polymorphism is localized in intron 16 of the human ACE gene and corresponds to a repetitive sequence about 287 bp long $[18,19]$.

In our clinical experience, some individuals with common bile duct stones are hospitalized more than once for treatment of biliary pancreatitis or for cholangitis. Why do some of the people with common biliary duct stone suffer cholangitis, while others develop pancreatitis? The answer to this question is not yet quite clear. Angiotensin is a proinflammatory molecule and may have a role in cholangitis (an infectious disease) and pancreatitis (a sterile inflammation). To determine if the ACE genotype determines the occurrence of cholangitis or biliary pancreatitis, we studied patients with these diseases and healthy controls.

\section{MATERIALS AND METHODS}

Forty-four patients with biliary pancreatitis and 31 patients with common bile duct stone and cholangitis hospitalized at the Department and Intensive Care
Faculty of Medicine, Ege University, Bornova, İzmir, Turkey, and 157 healthy individuals were studied. Patients with common bile duct stone and cholangitis did not have pancreatitis on the basis of radiological, laboratory and clinical tests. All patients and healthy control individuals were over 18 years of age, were informed about the study and consented to take part; they also consented to be recalled after 4 years.

All patients were checked for fasting blood sugar, blood urea, creatinine, serum alanine aminotransferase (ALT), serum aspartate aminotransferase (AST), serum alkaline phosphatase, gamma-glutamyltransferase (GGT), serum amylase, serum lipase, serum lactate dehydrogenase (LDH), sodium $(\mathrm{Na})$, potassium $(\mathrm{K})$, calcium $(\mathrm{Ca})$, serum total cholesterol, trigylcerides, serum high density lipoprotein (HDL), serum low-density lipoprotein (LDL) and serum very low density lipoprotein (VLDL) levels. Complete blood counts (CBCs), whole abdominal ultrasonography and abdominal tomography were performed on all patients. All patients had abdominal pain, fever, raised ALT, AST and serum alkaline phosphatase levels, whereas pancreatitis patients only had elevated amylase levels. The serum bilirubin level was above $2 \mathrm{mg} / \mathrm{dL}$ in all patients. Endoscopic retrograde cholangiopancreatography (ERCP) and sphincterectomy were performed on all patients.

The cholangitis and biliary pancreatitis patients were recalled 4 years later and their prognosis was evaluated. For detection of the ACE polymorphism, blood specimens from all participants were obtained by standard venipuncture into ethylenediamine tetraacetic acid-containing tubes. DNA was isolated by a standard phenol/chloroform extraction method [14].

We used the polymerase chain reaction (PCR) methodology [19] with an upstream primer (5'-CTG GAGACC ACT CCC ATC CTT TCT-3') and a downstream primer (5'-GAT GTG GCC ATC ACA TTC GTC AGA T-3'). Amplification was performed for 35 cycles with denaturation, extension and annealing temperatures of $94.8^{\circ} \mathrm{C}, 60.8^{\circ} \mathrm{C}$ and $72.8^{\circ} \mathrm{C}$, respectively. The resulting PCR products were separated on $2 \%$ agarose gel with ethidium bromide staining and visualized under ultraviolet light. Homozygotes for the deletion or insertion genotypes were described as DD and II, respectively, and the heterozygotes were reported as ID.

All statistical analyses were performed using the SPSS 11.0 statistical program. Genotypes, allele fre- 
quency, and clinical features at diagnosis were evaluated by the $\chi 2$ test. Clinical data are reported as mean $\pm \mathrm{SD}$ (standard deviation) and as percentages. Statistical significance was accepted as $p<0.05$.

\section{RESULTS}

There was no significant difference between the mean ages of acute pancreatitis and cholangitis patients, however, they were higher than those of the healthy control individuals $(p<0.05)$. There was also was no significant difference between cholangitis and biliary pancreatitis cases regarding the genotype and allele distribution $(p>0.05)$.

Genotype distribution of the ACE gene in acute pancreatitis, cholangitis and healthy controls are summarized in Table 1. The ACE II genotype frequency was found to be higher in cholangitis and biliary pancreatitis patients when compared with the healthy control individuals $(p<0.05)$.

In the evaluation of the patients 4 years later, 16 biliary pancreatitis patient were found to have had another bout within this period, and one case had two bouts twice within the same period. Six patients in the group with cholangitis suffered from cholangitis within this period, but none had experienced pancreatitis during the last 4 years.

Genotype distribution of the ACE gene in acute pancreatitis, cholangitis and patients with recurrent disease are summarized in Table 2. Recurrence of infection occurred more frequently in the patients with the DD genotype, although it was not significant according to the first assessment $(p>0.05)$.

\section{DISCUSSION}

Gallstone disease is a common disorder of the gastrointestinal tract. The prevalence of gallstones in the United States is approximately 10 to $15 \%$. Symptoms occur in approximately $20 \%$ of those with gallstones, and this group is at the highest risk for serious complications from simple recurrent biliary colic to severe, life-threatening ascending cholangitis and/or pancreatitis [20]. This is the first

Table 1. Genotype distribution of the angiotensin-converting enzyme in acute pancreatitis, cholangitis and healthy controls

\begin{tabular}{|l|c|c|c|c|}
\hline Genotype & Acute Pancreatitis $n(\%)$ & Cholangitis $n(\%)$ & Healthy Controls $n(\%)$ & $p$ Value \\
\hline DD & $11(25.0)$ & $7(22.0)$ & $61(38.0)$ & N.S. \\
\hline DI & $24(54.0)$ & $18(58.0)$ & $82(52.0)$ & N.S. \\
\hline II & $9(20.0)$ & $6(19.0)$ & $14(8.0)$ & $<0.05$ \\
\hline D (allele frequency) & $46(52.2)$ & $32(51.0)$ & $204(64.9)$ & N.S. \\
\hline I (allele frequency) & $42(47.8)$ & $30(49.0)$ & $110(35.1)$ & N.S. \\
\hline
\end{tabular}

Table 2. Genotype distribution of the angiotensin-converting enzyme in acute pancreatitis, cholangitis and patients with recurrent disease

\begin{tabular}{|l|c|c|c|c|}
\hline Genotype & $\begin{array}{c}\text { Acute Pancreatitis } \\
n(\%)\end{array}$ & $\begin{array}{c}\text { Recurrent Pancreatitis } \\
n(\%)\end{array}$ & $\begin{array}{c}\text { Cholangitis } \\
n(\%)\end{array}$ & $\begin{array}{c}\text { Recurrent Cholangitis } \\
n(\%)\end{array}$ \\
\hline DD & $11(25.0)$ & $6(35.2)$ & $7(22.0)$ & $2(33.2)$ \\
\hline DI & $24(54.0)$ & $8(47.0)$ & $18(58.0)$ & $3(50.0)$ \\
\hline II & $9(20.0)$ & $6(17.8)$ & $6(19.0)$ & $1(17.8)$ \\
\hline D (allele frequency) & $46(52.2)$ & $20(50.0)$ & $32(51.0)$ & $7(63.6)$ \\
\hline I (allele frequency) & $42(47.8)$ & $20(50.0)$ & $30(49.0)$ & $4(36.4)$ \\
\hline
\end{tabular}

The $p$ value was not significant. 
study to evaluate the role of the ACE gene polymorphism in cholangitis and pancreatitis. The ACE gene insertion/deletion polymorphism has been studied in several inflammatory diseases, such as urinary tract infections, acute pyelonephritis, in children with sepsis and septic shock, sepsis-induced acute respiratory distress syndrome (ARDS) and osteoarthritis [22-27]. In Turkey, patients who were carriers of the I allele ( I/D and II genotypes) had increased risk of developing sepsis compared to the control group [23]. A study from Korea found that the frequency of the I allele was significantly higher in early osteoarthritis [26]. The other study with inflammation and infections did not find any correlation between inflammation, infections and ACE gene polymorphisms [22,24,25, 27].

We found no statistical significant difference in frequency of this polymorphism between cholangitis and biliary pancreatitis patient groups. However, the ACE II genotype frequency was significantly higher in cholangitis and biliary acute pancreatitis than in healthy controls. In the European population, the ratio for the $\mathrm{DD} / \mathrm{ID} / \mathrm{II}$ was found to be $1: 2: 1$, respectively, but in Turkey the ratio for DD/DI/II genotype is $2 / 3 / 1$ [27,28]. Ethnic variation and gender have been reported to play a significant role in the frequency of the ACE I/D genotype [26].

Homozygous deletions (DD) show highest ACE activity, whereas, conversely, homozygous insertion (II) exhibits lowest ACE activity in the inflammatory process [17]. In carriers of the I allele (I/D and II genotype), the bradykinin inactivity is decreased because of lower ACE activity [17]. Therefore, depressed angiotensin II cannot sufficiently inactivate bradykinin, which has a major implication in the inflammatory process and this may be the reason for inflammation.

The ACE II genotype frequency may have a relationship with inflammation, however, it is remarkable that the ACE DD genotype frequency is higher in patients having a recurrence of cholangitis and/or pancreatitis. An interesting result of our study was that cholangitis patients experienced a recurrence of cholangitis, while patients who had biliary pancreatitis exhibited recurrence biliary pancreatitis. In conclusion, the ACE gene polymorphism in patients with a common bile duct gallstone had no effect in determination of the development of cholangitis or pancreatitis.

\section{REFERENCES}

1. Van Erpecum KJ. Gallstone disease. Complications of bile-duct stones: acute cholangitis and pancreatitis. Best Pract Res Clin Gastroenterol 2006; 20(6): 1139-1152.

2. Browning JD, Sreenarasimhaiah J. Gallstone disease. In: Sleisenger MH, Feldman M, Friedman L, Brandt LJ, Eds. Gastrointestinal and Liver Disease: Pathophysiology, Diagnosis, Management, 8th ed. Philadelphia: Saunders Elsevier. 2006; 13871418.

3. Attasaranya S, Fogel EL, Lehman GA. Choledocholithiasis, ascending cholangitis, and gallstone pancreatitis. Med Clin North Am 2008; 92(4):925960.

4. Hanau LH, Steigbigel NH. Acute (ascending) cholangitis. Infect Dis Clin North Am 2000; 14(3): 521-546.

5. Lipsett PA, Pitt HA. Acute cholangitis. Front Biosci 2003; 8:s1229-1239.

6. Lillemoe KD: Surgical treatment of biliary tract infections. Am Surg 2000;66(2): 138-144.

7. James H, Grendell MD. Acute pancreatitis In: James HG, Friedman SL, McQuaird KR, Eds. Current Diagnosis and Treatment in Gastroenterology, 2nd ed. New York: McGraw-Hill. 2003; 489-495.

8. Pandol SJ. Acute pancreatitis. Curr Opin Gastroenterol 2006; 22(5): 481-486.

9.Steinberg WM, Tenner S. Acute pancreatitis. N Engl J Med 1992 330(17): 1198-1994.

10. Raraty MG, Finch M, Neoptolemos JP. Acute cholangitis and pancreatitis secondary to common duct stones: management update World J Surg 1998;22(11): 1155-1161.

11. Lerch MM, Saluja AK, Rünzi M, Dawra R, Saluja M, Steer ML. Pancreatic duct obstruction triggers acute necrotizing pancreatitis in the opposum. Gastroenterology 1993; 104(3): 853-861.

12. Bhaskar S, Reddy DN, Mahurkar S, Rao GV, Singh L, Chandak GR. Lack of significant association of an insertion/deletion polymorphism in the angiotensin converting enzyme (ACE) gene with tropical calcific pancreatitis. BMC Gastroenterol 2006; 6:42-49.

13. Paul M, Mehr AP, Kreutz R. Physiology of local renin-angiotensin systems. Physiol Rev 2006; 86(3): 747-803.

14. Leung PS. The peptide hormone angiotensin 
II: its new functions in tissues and organs. Curr Protein Pept Sci 2004; 5(4): 267-273.

15. Oruc N, Lamb J, Kutlu OC, Barmada MM, Money ME, Slivka A, Whitcomb DC. The functional angiotensin converting enzyme gene I/D polymorphism does not alter susceptibility to chronic pancreatitis JOP 2004; 10(5): 457-463.

16. Oruc N, Papachristou G, Avula H, Slivka A, Lamb J, Whitcomb DC, Angiotensin-converting enzyme gene DD genotype neither increases susceptibility to acute pancreatitis nor influences disease severity. HPB (Oxford) 2009; 11(1): 45-49.

17. Knoefel WT, Kollias N, Warshaw AL, Waldner H, Nishioka NS, Rattner DW. Pancreatic microcirculatory changes in experimental pancreatitis of graded severity in rat. Surgery 1994; 116(5): 904913.

18. Lai PB. Local renin-angiotensin system in the pancreas: the significance in acute pancreatitis. JOP 2001; 2(1): 13-15.

19. Rigat B, Hubert C, Alhenc-Gelas F, Cambien F, Corvol P, Soubrier F. An insertion/deletion polymorphism in the angiotensi I-converting enzyme gene accounting for half the variance of serum enzyme levels. J Clin Invest 1990; 86(3): 1343-1346.

20. Browning JD, Horton JD. Gallstone disease and its complications. Semin Gastrointest Dis 2003; 14(4): 165-177.

21. Sekerli E, Katsanidis D, Vavatsi N, Makedou A, Gatzola M. ACE gene insertion/deletion polymorphism and renal scarring in children with urinary tract infections. Pediatr Nephrol 2009; 15(10): 1975-1980.

22. Cho SJ, Lee SJ. ACE gene polymorphism and renal scar in children with acute pyelonephritis. Pediatr Nephrol 2002; 17(7): 491-497.

23. Cogulu O, Onay H, Uzunkaya D, Gunduz C, Pehlivan S, Vardar F, Atlihan F, Ozkinay C, Ozkinay $\mathrm{F}$. Role of angiotensin-converting enzyme gene polymorphisms in children with sepsis and septic shock. Pediatr Int 2008; 50(4): 477-480.

24. Villar J, Flores C, Pérez-Méndez L, MacaMeyer N, Espinosa E, Blanco J, Sangüesa R, Muriel A, Tejera P, Muros M, Slutsky AS; GRECIA Group; GEN-SEP Group. Angiotensin-converting enzyme insertion/deletion polymorphism is not associated with susceptibility and outcome in sepsis and acute respiratory distress syndrome. Intensive Care Med 2008; 34(3): 488-495.

25. Shehab DK, Al-Jarallah KF, Alawadhi AM, Al-Herz A, Nahar I, Haider MZ. Prevalence of angiotensin-converting enzyme gene insertion-deletion polymorphism in patients with primary knee osteoarthritis. Clin Exp Rheumatol 2008; 26(2): 305-310.

26. Hong SJ, Yang HI, Yoo MC, In CS, Yim SV, Jin SY, Choe BK, Chung JH. Angiotensin converting enzyme gene polymorphism in Korean patients with primary knee osteoarthritis. Exp Mol Med 2003; 35(3): 189-195.

27. Celik US, Noyan A, Bayazit AK, Büyükçelik M, Dursun H, Anarat A, Attila G, Matyar S. ACE gene polymorphism in Turkish children with nephrotic syndrome. Renal Fail 2006; 28(5): 401-403.

28. Degirmenci I, Kebapci N, Basaran A, Efe B, Gunes HV, Akalin A, Kurt H, Urhan M, Demirustu C. Frequency of angiotensin-converting enzyme gene polymorphism in Turkish type 2 diabetic patients. Int J Clin Pract 2005; 59(10): 1137-1142. 